\title{
TRICHINOSIS IN THE ARCTIC: A REVIEW
}

By Frank H. Connell*

$\mathbf{F}^{\mathrm{o}}$ or over one hundred years the microscopic roundworm, Trichinella spiralis, has been known as a parasite of man and many other mammals. Its distribution is fairly cosmopolitan with the highest incidence of infection in both man and animals reported in the Northern Hemisphere. The ability of Tricbinella to live in a wide variety of hosts and its peculiar life cycle which, unlike that of other nematodes, is completed within the body of a single host, have contributed to its success as a parasite in regions which many parasites find inhospitable.

A discussion of the effects of Tricbinella upon the body is beyond the scope of this paper. However, it may prove helpful to those readers who have not been trained in medicine or parasitology if illustrations and a brief description of the life cycle of the parasite are included here.

Infection is established in the gut when viable larvae are ingested in infected meat (Pls. 1 or 3). As many as 45,000 larvae per ounce have been found in the skeletal muscle of infected hogs. These, released from the meat by digestion, soon reach the small intestine. Here the larvae attach to or penetrate the intestinal lining. They mature rapidly and within 48 hours have become adults. The males die soon after fertilizing the females. These ordinarily outnumber the males by about two to one. Within a week the females begin to give birth to living young. During the next month or more each female may produce 1,000-1,500 offspring. The young larvae are deposited by the parent worm directly into the intestinal wall. Plate 2 shows in section such a female, well-embedded in the intestinal wall of an infected rat. Larvae, nearly ready for birth, can be seen in the uterus of the mother.

The young larvae enter the lymph vessels and make their way to the blood stream via the thoracic duct. Larvae are carried all over the body by the blood. They regularly enter and damage heart muscle but are unable to develop there. They may also damage the brain. Strays have been reported from many organs and cavities of the body. Further development of the larvae, however, is possible only in the skeletal or voluntary muscle of the body. In such muscle, the larvae leave the capillaries of the circulatory system and enter muscle fibres. All muscle fibrils in the immediate vicinity of the larvae are destroyed.

During the next month the larvae grow to a length of about $1 \mathrm{~mm}$. and coil within the muscle fibre. However, larvae develop enough to be infective if eaten by another suitable host (Pl. 1) after about ten days residence in a muscle fibre. Within a month a capsule, elaborated by the body, can be seen about the young worm. The wall of the capsule

\footnotetext{
*Professor of Zoology, Dartmouth College, and Parasitology, Dartmouth Medical School.
} 


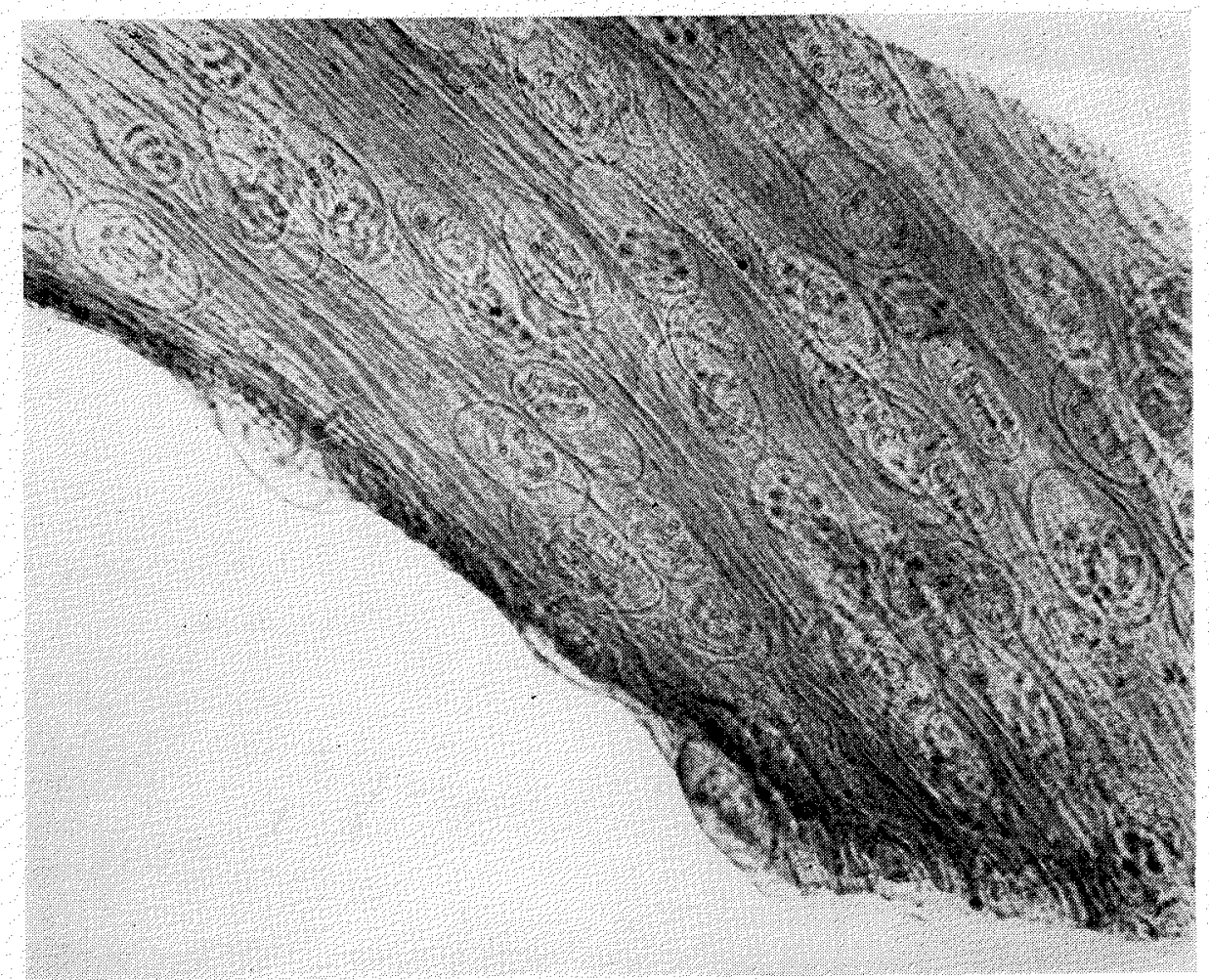

Plate 1. Infective Trichinella larvae in a strip of rat diaphragm. Encapsulation has begun. Larvae have been present in this tissue about two months. $\mathrm{X} 30$.

thickens and after about five months calcification of the wall may begin. The worm lies dormant within the capsule and may live for years. Plate 3 shows a heavily encapsulated larva of perfectly normal appearance found at autopsy in the diaphragm of a man reputed to have had trichinosis many years before. It is important to remember that encapsulated larvae only reach the adult state when they are eaten in raw or imperfectly cooked meat by a suitable host.

Trichinella, like hookworm, injures its host in direct proportion to the number of viable larvae that gain entrance to the host's body. Fortunately most Trichinella infections in man are so light as to escape recognition, but in both man and animals the heavier infections result in serious illness and may terminate fatally.

The diagnosis of even severe infections cannot be made with certainty unless the aid of modern serological and other laboratory tests is available. When one considers the great areas of the Arctic that are without the services of a physician and the primitive nature of laboratory facilities in those areas where medical care is available, it is not surprising that trichinosis has until recently escaped recognition in Arctic populations. 


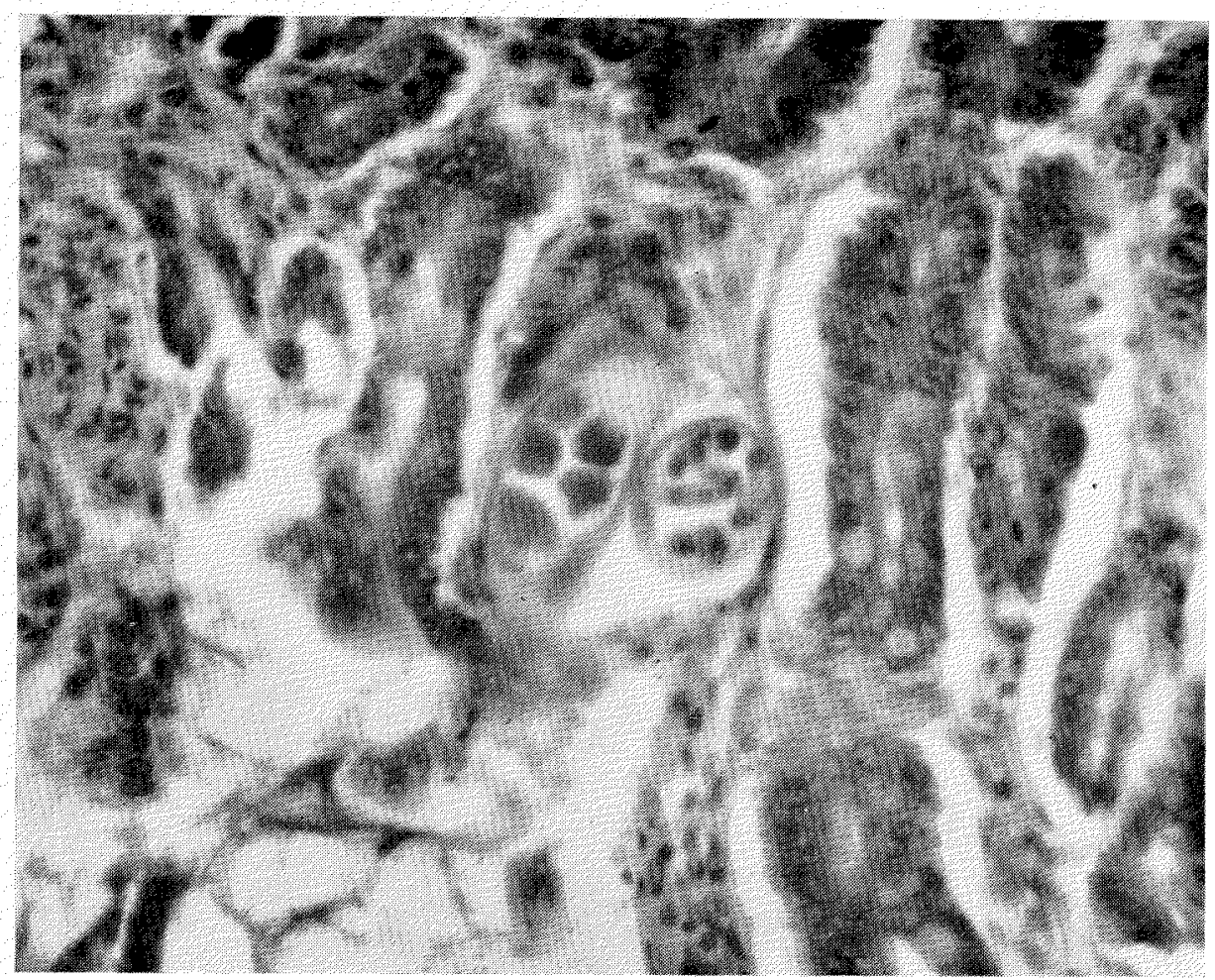

Plate 2. Histologic section gravid female Trichinella in small intestine of rat about ten days after infection. X 220 .

In retrospect it must be admitted that at least three writers sounded warnings which if heeded would have resulted in the discovery of Tricbinella infection of man in the Arctic many years ago.

As far back as 1914 Stefansson suggested trichinosis rather than ptomaine poisoning as a possible cause of death from eating the meat of the white whale. ${ }^{1}$ There was even less reason to ignore the warning of Parnell (1934) who, on finding Trichinella larvae in the muscle of polar bear and arctic fox, wrote: "Rather more in the realm of speculation is the part the Trichina worm may play in those deaths of whole families which are periodically reported among the Eskimos. These wholesale deaths are always ascribed to "ptomaine" poisoning: without, however, any real evidence.... In the north, the dog is the all important animal, but this preliminary survey has made it obvious that their power to work must be considerably decreased and death not infrequently caused by internal parasites." ${ }^{2}$ Likewise, R. T. Leiper (1938), who found Trichinella in polar bear and arctic foxes that had died in the London Zoological Gardens, pointed out the risk to explorers and their dogs if polar bear meat or the flesh of other dogs was used to replenish food supplies. ${ }^{3}$ 


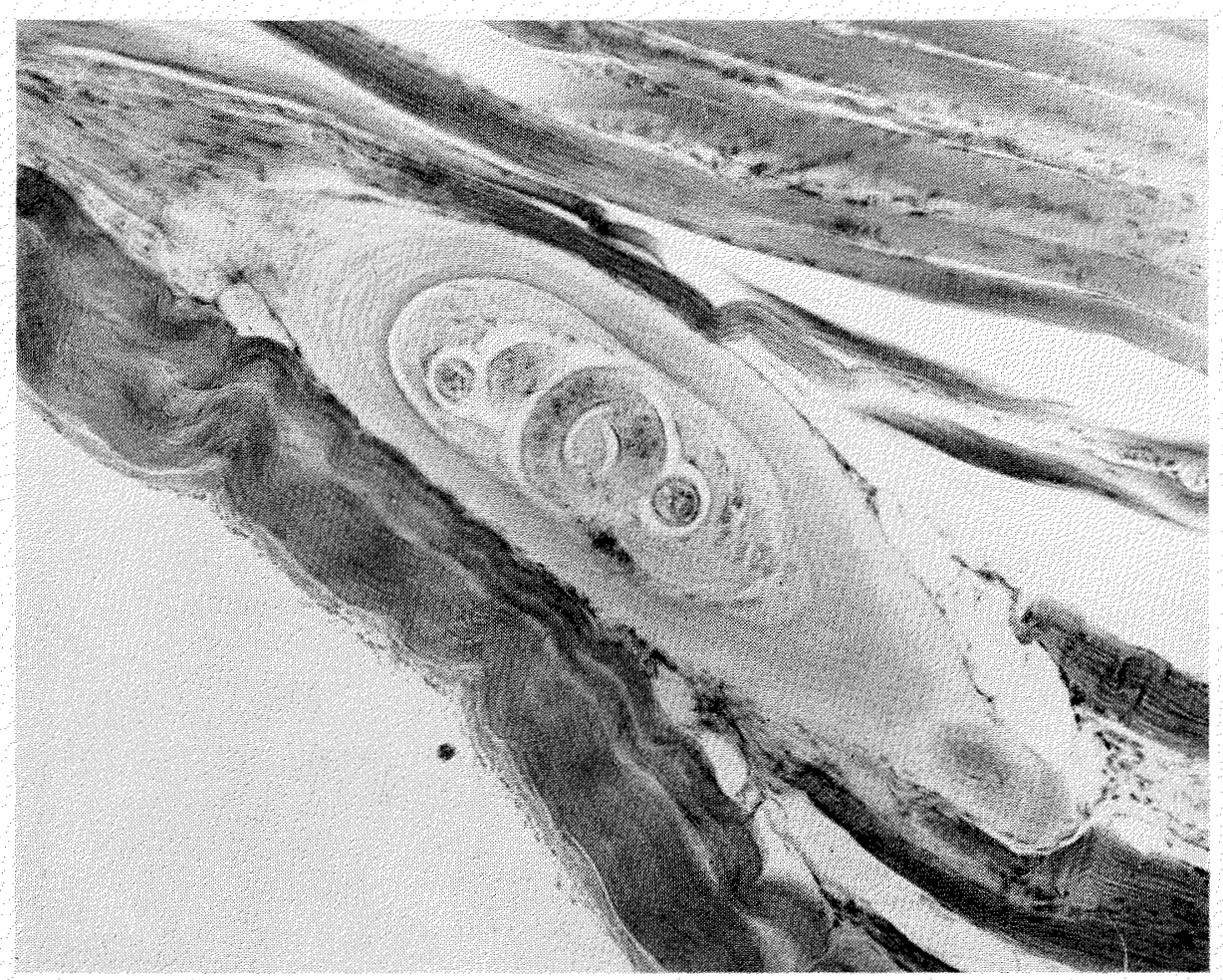

Plate 3. An encapsulated Trichinella larva in diaphragm of man long recovered from trichinosis. Such larvae may remain infective for years. $\mathrm{X} 110^{*}$.

Recently interest in trichinosis as an international health problem of the circumpolar regions has developed rapidly as the result of positive: identification of the parasite in man in such widely separated areas as Alaska, the Canadian Arctic, Greenland, northern Europe and Siberia.

Capt. John Giaver of the Norsk Polarinstitutt, writing to Dr. Stefansson in September 1948, reported an epidemic of trichinosis which broke out among the personnel of a secret German weather station based on Frans Josef Land during World War II. Some fifteen men who acquired the infection from polar bear meat in the spring of 1944 became so seriously ill that it was necessary to remove them to Norway by plane for hospitalization. There were no deaths, but several patients required long periods. for convalescence. A report of this epidemic appeared in Arctic Vol. 1 (1948) p. 144.

This, so far as I have been able to determine, is the first accurately identified epidemic of Arctic-acquired trichinosis in man. It now appears that an epidemic in Stuttgart, Germany during 1930, seriously affecting some 100 persons and responsible for 13 deaths, was probably of Arctic

*All photographs reproduced were taken by the Department of Photography, Mary Hitcheock Memorial Hospital, Hanover, N.H. 
origin. Dr. Roth, writing to Dr. Stefansson, has called attention to three papers in the German literature dealing with this epidemic. ${ }^{4,5,6}$ In brief, these cases were traced to the smoked ham of a polar bear which had been served by an innkeeper. As the bear had been slaughtered in a zoo it was thought at the time that its infection had been acquired in captivity. In the light of present knowledge this seems to have been an unnecessary assumption.

On the initiative of Dr. Stefansson an active correspondence concerning trichinosis in the Arctic developed during the past year. Many workers in both North America and Europe pooled their information and, with Dr. Stefansson acting as a clearing house, carbon copies of numerous letters were distributed to those interested. The writer is grateful for the privilege of reviewing these letters in the preparation of this article.

Two studies, now published, establish as fact the prediction made by Parnell ${ }^{2}$ fifteen years ago and cited above. One, the work of a Queen's University medical team headed by Dr. Malcolm Brown, included examination of two-thirds of the native population of Southampton Island, N.W.T. for trichinosis during the summer of 1948 . Some 51 per cent gave a positive reaction to the skin test. Suggestive histories and a high incidence of eosinophilia, discovered by a previous Queen's University expedition in 1947 , directed the investigators attention to trichinosis. Dr. Kuitunen-Ekbaum, who was a member of the team, examined muscle from polar bear, walrus, seal and the white whale. Trichinella was found only in the bear; two of three examined proved to be infected. ${ }^{7,8,9}$

Of even greater interest is the second study which includes medical and epidemiological observations made during the course of an extensive epidemic in West Greenland during the spring of 1947 by Thorborg, Tulinius, and Roth. ${ }^{10}$ Dr. Roth, long highly regarded as an investigator and author of many papers on trichinosis, has been among the most active contributors to Dr. Stefansson's "trichinosis circle".

The epidemic which Dr. Roth and his co-workers reported was not only the first recognized in Greenland but the first to be studied anywhere in the Arctic. Approximately 300 native Greenlanders were attacked and 33 died. All except two of the cases were confined to the region between Disko Bay and Holsteinsborg. The epidemiology of this epidemic is of special concern to everyone interested in the disease. Pork was excluded as a source of infection. Very strong evidence indicated walrus meat as the cause of most cases. A few persons probably acquired their infection from dog flesh and in another group of cases suspicion was directed toward meat of the white whale. Unfortunately by the time the epidemic developed and the investigators had arrived on the scene none of the suspect meat was available for examination. Subsequent investigation indicates that Trichinella infection in sea mammals is sporadic but 
it is clear that a single heavily infected walrus could account for a large number of cases.

No other epidemics of trichinosis have been studied in the North but enough scattered cases, reported below, have accumulated to establish the circumpolar distribution of the disease.

Dr. Ralph B. Williams has reported the death of a boy from trichinosis at Wainwright, Alaska in February 1946 and serious infections in three men at Cape Yakataga, Alaska in the fall of $1945 . .^{11}$ All four of these cases were acquired from bear meat. Working at Point Barrow, Alaska, Dr. Robert Rausch has reported positive skin tests in two natives in a letter to Dr. Stefansson. Dr. Rausch has also examined a number of animals for Trichinella; his results to date are included in the table which appears below.

Dr. Alwin Pedersen is quoted by Dr. Roth as having recollection of a short article in a Russian journal which reported trichinosis acquired from polar bear on the Chukotski Peninsula, Siberia during the years immediately preceding World War II. ${ }^{12}$ These observations, together with the the discovery of Trichinella in 7 of 8 polar bears and in a sledge dog from Spitsbergen by Prof. Aaser, reported in a letter from Capt. Giaver, make it clear that no portion of the Arctic can be regarded as free from the disease.

Tricbinella can pass from one host to another only when the infected meat of the first host is eaten raw or imperfectly cooked by a second suitable host. Because the flesh of wild animals plays such an important role in the diet of Arctic populations it seems worthwhile to attempt an evaluation of the danger which each of the species so far examined may be to man in the Arctic.

From the letters and papers of various workers it has been possible to compile the table on page 104 .

While more extensive investigation is desirable, the pattern of distribution of Trichinella among arctic mammals is already quite clear.

The economic importance of the dog protects man, except in case of emergency, from infection by this most dangerous source. Sea mammals should be protected by their habits from all but sporadic infection, and the number of negative examinations reported to date seems to support this conclusion. The bear remains as the one important food animal from which a real threat of infection is constant.

In a letter to Dr. Thomas W. M. Cameron, dated 19 November 1948, Dr. Stefansson says, ". . . when we were travelling over the sea ice far from land and living exclusively by hunting, about 90 per cent of our food was seals, 10 per cent polar bears." 
Possible Host

$$
\text { Dog }
$$

Total

Polar Bear

Bearded Seal

Other Seals

Total

Walrus

Total

White Whales

Total

Narwhal

Arctic Fox

Total

Red Fox

Greenland Hare

Lemmings

Rattus norvegicus

$$
\begin{gathered}
\text { No. No. } \\
\text { Examined Positive Positive }
\end{gathered}
$$

Locality

Observer

Greenland

Alaska

Spitsbergen

Roth (11 and letter)

Rausch (letter)

76

11

72

$\begin{array}{lll}83 & 60 & 72\end{array}$

$\begin{array}{ll}\text { Greenland } & \text { Roth } \\ \text { Spitsbergen } & \text { Aaser } \\ \text { Alaska } & \text { Rausch } \\ \text { Southampton I. } & \text { Brown et al }(8,9) \\ \text { Canadian Arctic } & \text { Parnell }(2) \\ \text { Siberia } & \text { Pedersen via Roth }\end{array}$

$\begin{array}{ll}9 & 6 \\ 8 & 7 \\ 3 & 2 \\ 3 & 2 \\ ? & ? \\ ? & ?\end{array}$

$33+17+51$ 
Fortunately the culinary habits of Arctic populations give some degree of protection from Trichinella infection. In the North meat may be eaten both frozen and raw but usually, except in periods of fuel scarcity or haste, it is boiled. If meat is cooked thoroughly or if it is frozen hard enough for long enough Trichinella larvae are either killed or rendered non-infective. In the more primitive areas cooking is very slow. Meat, cut in pieces, is put in a pot with ice or water and brought to a boil. The pot is then set aside and permitted to cool before eating. As a result the smaller pieces tend to be well done but the larger pieces are often pink at the centre and are dangerous.

It should be emphasized here that with both cooking and freezing it is essential that the size of the piece of meat be given proper consideration. Few people realize how long it takes to bring about sufficient temperature change in the centre of a large piece of meat to destroy larvae. Ransom and Schwartz (1919) placed the upper thermal death point of larvae at $131^{\circ} \mathrm{F}$. and recommended sufficient cooking to raise the temperature of all parts of a piece of meat to $137^{\circ} \mathrm{F} .\left(58.33^{\circ} \mathrm{C}\right.$.).$^{13}$ Ransom (1916) further showed that a 15 pound ham cooked in water at $180^{\circ} \mathrm{F}$. required $2 \frac{1}{2}$ hours to raise the temperature at the centre of the ham from $78^{\circ} \mathrm{F}$. to $137^{\circ} \mathrm{F}$. and $3 \frac{1}{2}$ hours to raise the temperature at the centre from $46^{\circ} \mathrm{F}$. to $137^{\circ} \mathrm{F}^{14}$ It must be remembered how very much more time will be required to raise a comparable piece of frozen' but still infective polar bear meat to $137^{\circ} \mathrm{F}$.

A number of workers have investigated the lower thermal death point for Trichinella larvae. Here again many factors such as the size of the piece, the age of the larvae, the temperature used, the speed of freezing, and the time for which the meat is held at low temperature affect the success of the procedure. Ransom (1916) determined that meat held at $5^{\circ} \mathrm{F} .\left(-15^{\circ} \mathrm{C}\right.$.) for 20 days is non-infective. This allows a week or ten days as a probable margin of safety. Ransom also showed that a barrel of meat at $0^{\circ} \mathrm{C}$. when placed in a refrigerator at $-15^{\circ} \mathrm{C}$. requires about 7 days before the centre of the barrel reaches the temperature of the refrigerator. ${ }^{14}$ More recent work by Gould and Kaasa (1949) has shown that very low temperatures kill larvae rather more rapidly. They conclude that "the following temperatures maintained for the designated periods, in the central portions of pork, are believed to be effective in killing all trichina larvae which may be present: $-27 \mathrm{C}(-16.6 \mathrm{~F})$ maintained for 36 hours; $-30 \mathrm{C}(-22 \mathrm{~F})$ maintained for 24 hours; $-33 \mathrm{C}(-27.4 \mathrm{~F})$ maintained for 10 hours; $-35 \mathrm{C}(-31 \mathrm{~F})$ maintained for 40 minutes; $-37 \mathrm{C}(-34.6 \mathrm{~F})$ maintained for 2 minutes." 15

It would be interesting to know how often in the storage or preparation of food by a primitive society either the lower or upper thermal death point is achieved. 
In populations as regularly exposed to Trichinella infection as those of Arctic regions, the possibility of developing in man a long-lasting protective immunity from an original sub-clinical infection becomes a question of more than academic importance. Many workers have shown that during light Tricbinella infections a number of laboratory animals can actively acquire a real protective immunity to subsequent reinfections. Unfortunately with regard to man the evidence is not entirely clear. Unquestionably both cellular and humoral responses to Trichinella develop in man, but it is doubtful whether these are adequate to prevent clinical trichinosis in a sensitized person who, at some later date, again swallows a heavy dose of viable larvae. Gould, in his outstanding monograph, pp. 134-135, cites at least six papers giving recorded reinfections of man that resulted in second or even third attacks of clinical trichinosis. ${ }^{16}$

Two puzzling questions pertaining to trichinosis in the Arctic remain to be discussed:

The first is when did Tricbinella first invade the Arctic? This question probably will never be answered. The holarctic distribution of the worm in Europe, and perhaps North America, certainly goes back to ancient times. The wide distribution of the worm in the Arctic at the present argues against recent introduction. Parnell found it there in animals fifteen years ago, and it seems probable that the disease has been present there in man as well, masquerading for many years under other names.

The second question concerns the incidence of Trichinella in the polar bear. Further work may soon provide an answer but at present it is difficult to explain the 51 per cent incidence of Trichinella in the polar bear examined to date. Such an incidence greatly exceeds anything found in the United States even among hogs and rats that have been permitted to feed upon slaughter house offal. Given a high incidence in the bear, the incidence in dog and man is not hard to understand. If the lemming or the seal or some common cannibalistic item in the bears' diet had proved to be regularly infected no question would remain. At present, however, the only tenable hypothesis has been offered by Dr. Roth. He suggests that terrestrial carnivores (bear, dog, fox) obtain the infection by eating the carcasses of other bears, dogs, and foxes. He points out that Söntgen has shown the red fox to acquire most of its Trichinella by eating the skinned carcasses of other red foxes. ${ }^{17}$ This is in agreement with the observation in the United States that hogs fed on uncooked garbage containing pork scraps have a much higher incidence of Tricbinella infection than grain-fed hogs or hogs permitted to roam the woods.

For the future, it is difficult to see how trichinosis can ever be less than a major public health problem of the Arctic so long as man depends for food upon the spoils of the chase. In the United States, education of 
the housewife and the wide-spread use of deep-freeze units on farms leads one to hope that the disease will become less common. In the Arctic, education of native populations may reduce somewhat the incidence of trichinosis but on the whole we may expect to see in the mirror of today a reflection of tomorrow.

\section{Summary}

1. Trichinella spiralis in man and animals is now known to have a circumpolar distribution.

2. Infection of sea mammals is sporadic. Among land mammals only the polar bear and sledge dog show an alarmingly high and dangerous incidence.

3. Trichinosis in the Arctic is a major public health problem for which there appears to be no immediate practical solution.

\section{REFERENCES}

${ }^{1}$ Stefansson, V. "The Stefansson-Anderson Arctic Expedition: Preliminary ethnological report". Antbropol. Pap. Am. Mus. Nat. Hist. 14 (1914) p. 449.

2Parnell, I. W. "Animal parasites of North-East Canada". Can. Field Naturalist 48 (1934) pp. 111-115.

${ }^{3}$ Leiper, R. T. "Trichinosis in arctic animals". Proc. Zool. Soc. Lond. 108, Ser. C. (1938) pp. 13-14.

${ }^{4} v$. Ostertag, R. "Die Trichinose nach Genuss von Bärenfleisch in Stuttgart und die Folgerungen hieraus für die Organisation der Trichinenschau". Zeit. f. Fleisch-u. Milchbyg. 40 (1930) pp. 289-291.

${ }^{5}$ Stehle, M. "Ueber Trichinose bei wilden Tieren und ihre Uebertragung auf den Menschen". Zeit. f. Infektionskrankbeiten, parasitäre Krankbeiten und Hygiene der Haustiere 39 (1931) pp. 320-329.

${ }^{6}$ Weitz, W. "Zur Symptomatologie der Trichinose". Zeit. f. klin. Medizin 116 (1931) Pp. 144-173.

TBrown, Malcolm, Sinclair, R. G., Cronk, L. B., and Clark, G. C., with KuitunenEkbaum, E. "Intestinal parasites of Eskimos on Southampton Island, Northwest Territories". Can. J. Pub. Health 39 (1948) pp. 451-454.

${ }^{8}$ Brown, Malcolm, Cronk, B., deSinner, F., Green, J. E., Gibbons, J. E., and KuitunenEkbaum, E. "A note on trichinosis in animals of the Canadian Northwest Territories". Can. J. Pub. Healtb 40 (1949) pp. 20-21.

"Brown, Malcolm. "Medical investigation at Southampton Island". Arctic 2 (1949) pp. 70-71.

${ }^{10}$ Thorborg, N. B., Tulinius, S., and Roth, H. "Trichinosis in Greenland". Acta Path. et Microbiol. Scand. 25 (1948) pp. 778-794.

${ }^{11}$ Williams, R. B. "Bears and trichinosis". Alaska's Health 4 (1946).

${ }^{12}$ Roth, H. "Trichinosis in arctic animals". Nature 163 (1949) pp. 805-806.

13Ransom, B. H., and Schwartz, B. "Effects of heat on trichinae". J. Agri. Res. 17 (1919) pp. 201-221.

${ }^{14}$ Ransom, B. H. "Effects of refrigeration upon the larvae of Tricbinella spiralis". J. Agri. Res. 5 (1916) pp. 819-854.

${ }^{15}$ Gould, S. E., and Kaasa, L. J. "Low temperature treatment of pork: Effect of certain low temperatures on viability of Trichina larvae". Am. J. Hyg. 49 (1949) pp. 17-24.

${ }^{16}$ Gould, S. E. 'Trichinosis'. Thomas, Springfield, Ill., 1945.

${ }^{17}$ Söntgen, Karl. "Zur Frage der Fuchstrichinose". Zeit. f. Fleiscb-u. Milchyg. 49 (1939) pp. 334-336. 